\title{
Design of high performance and low resistive loss graphene solar cells
}

\author{
Mohammad Sabaeian ${ }^{1,2^{*}}$ and Yaser Hajati ${ }^{1,2}$
}

\begin{abstract}
Despite metallic plasmonic excitations can enhance the performance of ultra-thin solar cells however these socalled plasmonic solar cells suffer from a large resistive (Ohmic) loss caused by metallic elements. In this work, we report on a new design that uses graphene nanoribbons (GNRs) in a two-dimensional (2D) grating form at the top of the semiconductor-on-insulator (SOI) solar cells aimed to reduce the resistive loss. The results showed that GNRs can remarkably reduce the resistive loss compared to the SOI cell with Ag nanograting, while keeping all other cell's parameters, comparable with those of Ag SOI cell. Optical absorption and short-circuit current density of the graphene cells showed, respectively, enhancements of 18 and 1.7 times when optimizations were done with respect to width and the grating period. Our calculations showed that the graphene solar cells dissipate at most $5 \%$ of incident sunlight power as narrow and tiny peaks around $508 \mathrm{~nm}$, which is noticeably lower than those of Ag solar cells with high and broad band peaks with the maximum values of $29 \%$ at $480 \mathrm{~nm}$ and $24 \%$ at $637 \mathrm{~nm}$.
\end{abstract}

Keywords: Solar cell, Graphene, Resistive loss, Optical absorption, short-circuit current density

\section{Introduction}

Nowadays, the huge decrease in fossil energy resources and high cost of pollution control has forced scientists to search for sustainable energy sources. During the years, different methods have been introduced. Among them, the most important one that guarantees a clean and environmentally friendly technique, has benefited from the photovoltaic effect $[1,2]$. In spite of huge research which has been accomplished on solar cell topic, however, there are limitations on the massive production of solar cells. Regarding to this fact that the sunlight radiation covers almost a broad spectrum range, mainly from $290 \mathrm{~nm}$ in ultraviolet regime to $3200 \mathrm{~nm}$ in mid infrared one, for absorbing long wavelength photons, those which lie in near to mid infrared spectrum regime, thick absorption layers are needed [3]. Increasing the Si wafer thickness not only imposes additional cost, but also can cause junk recombinations, because of a short electron

\footnotetext{
* Correspondence: sabaeian@gmail.com

'Department of Physics, Faculty of Science, Shahid Chamran University of Ahvaz, Ahvaz, Iran

${ }^{2}$ Center for Research on Laser and Plasma, Shahid Chamran University of
} Ahvaz, Ahvaz, Iran

\section{Springer Open}

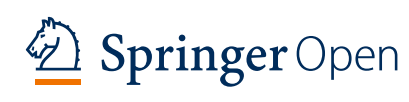

diffusion length $[1,2,4,5]$. At least, one can name three types of recombination: the electron jumps back from conduction band to valence band and recombines with a hole while a photon is emitted. This process is called band-to-band recombination, or radiative recombination. Reed-Shockley-Hall (RSH) recombination is assisted by trap energy levels in band gap. Auger recombination is a process in which an electron and a hole recombine in a band-to-band transition, but the resulting energy is given off to another electron or hole. In the case of hybrid solar cell, mismatch of different crystal lattices may cause a large number of dangling bond at the interface between two different materials. The interface recombination can be viewed as a type of $\mathrm{RSH}$ and the interface becomes major limiting factor resulting in rather high interface recombination velocity which thereby lowers the lifetime of carriers.

Due to the aforementioned difficulties, it was a necessity to find an alternative solution to enhance the light absorption in the thin solar cells. For the first time, in order to improve the carrier collection efficiencies, Redfield [6] introduced dielectric waveguide concept to confine and guide the scattered emission in a Si film with a

(c) The Author(s). 2020 Open Access This article is licensed under a Creative Commons Attribution 4.0 International License, which permits use, sharing, adaptation, distribution and reproduction in any medium or format, as long as you give appropriate credit to the original author(s) and the source, provide a link to the Creative Commons licence, and indicate if changes were made. The images or other third party material in this article are included in the article's Creative Commons licence, unless indicated otherwise in a credit line to the material. If material is not included in the article's Creative Commons licence and your intended use is not permitted by statutory regulation or exceeds the permitted use, you will need to obtain permission directly from the copyright holder. To view a copy of this licence, visit http://creativecommons.org/licenses/by/4.0/. 
$2 \mu \mathrm{m}$ thickness. The method used by Redfield means confining the light beams into a dielectric waveguide of a thin solar cell with an effective technique to enhance the light absorption. Yablonovitch, based on the ray optics, presented a statistical procedure toward measuring the enhancement factor for light intensity as $4 n^{2}$ for bulk absorption and $\mathrm{n}^{2}$ for surface absorption to make the process of solar cell fabrication much more cost effective [7]. Here $\mathrm{n}$ is the refractive index of semiconductor film,

Obtaining the highest efficiency in any design and experiment is indeed a precious goal. Authors have innovated various configurations to enhance the quantum efficiency as well as the short-circuit current density of solar cells $[8,9]$. For example, all-inorganic composition and suitable band gap of quantum dots (QDs) have been used in Perovskite solar cells to enhance the power conversion efficiency [10]. In the recent years, applying dielectric photonic crystals [3] and periodically patterned metallic structures [11] as back reflectors in order to enhance the electromagnetic energy intensity even beyond $4 n^{2}$ limit has become a popular trend. Using the plasmonic excitations in the ultra-thin solar cells, one can simultaneously increase the efficiency of solar cells and reduce the cost of film deposition [1, 4, 12-18] which are two favorite factors in experimental research. Using perovskite-hybrid plasmonic nanostructured, Zhang et al. have explained the role of plasmonic coupling and photonic cavities in enhancing light-matter interactions and manipulating carrier dynamics [19].

There are at least three main schemes for plasmonic structures to be integrated with a solar cell. The first method involves locating the plasmonic elements at the top of the solar cell [13, 20-22]. It provides us with two important advantages: improving the optical absorption in absorption layer through scattering of light into it and preventing the reflection back [23]. Embedding the plasmonic structures inside the absorption layer is another approach [24], in which plasmonic nanoparticles act as subwavelength lenses enabling enhancing the light absorption. The third method is to arrange a grating or striped-like plasmonic structures at the back surface of the solar cell [25-27]. In this method, surface plasmon polaritons (SPPs) are excited in the absorption layer, leading to an increase in the optical absorption. Furthermore, in this scheme, where plasmoic structures are served as a back contact [28], a short distance provides proper conditions for collecting the charge carrier to be collected.

To support the SPPs in the active layer of a solar cell, it is a crucial need to find the optimum plasmonic material. Although for many years gold and silver have been of the most interesting and extremely popular materials $[29,30]$, they impose limitations one practical applications such as energy loss from intraband transitions, large Ohmic losses at the optical frequencies caused by electron-electron scattering, electron-ion scattering, and inelastic scattering from defects and grain boundaries [31], lack of tunability, and difficulties during the fabrication process. Since the first investigation on plasmonic effect, silver has been the best choice for visible light applications, because it has the lowest Ohmic loss and a high onset of intraband transitions. For near infrared/ terahertz region, gold and copper can be used, but gold is usually preferred over copper since it doesn't oxidize and is therefore more stable. There are other materials that have lower losses than silver and gold such as sodium and potassium, however these materials are not stable and would therefore not be easy to be used in plasmonic devices. Nevertheless, due to the lack of tunability and difficulties during the fabrication process, they impose limitations on practical applications.

The discovery of graphene and other 2D materials such as hexagonal boron nitride (h-BN), transition metal chalcogenides to a class of monoelemental 2D materials ( $\mathrm{Si}, \mathrm{Ge}, \mathrm{Sn}$, etc.) which happened in "postgraphene age" triggered a wide range of research concerning 2D materials covering metals, semiconductors, and insulators, all with intriguing properties [32-34]. It has been shown that strongly confined surface plasmonic excitation in graphene with outstanding properties such as electrical tunability [35], low dissipative losses [36], strong lightmatter interactions [37], and extreme field confinement [38-40] can be a trustable substitution for noble materials. Compared with plasmons in noble metals, the electronic properties of graphene can be effectively controlled by changing the Fermi energy through the use of a gate voltage, chemical doping, and electric and magnetic fields [28]. Prominent properties of graphene along with its electronic [32-34, 41-43] and photonic [44-46] features have made it an interesting platform for plasmonic waveguiding applications [37, 47-49]. However, so far its abilities have been proven more in the terahertz and mid-infrared frequency range $[50,51]$ rather than optical spectral region [52] (http://pubs.acs. org/doi/abs/10.1021/acssuschemeng.5b01504), (https:// www.ncbi.nlm.nih.gov/pubmed/28295982). Patel et al. showed that multilayer graphene acts as an efficient transparent conducting electrode in a graphene/Si heterojunction solar cell [53]. Up to 40 layers of n-type graphene, the efficiency found to be constant and enhanced only to $7.62 \%$. After further optimization on the parameters of p-crystalline silicon wafer, a maximum efficiency of $11.23 \%$ has been achieved.

In this work, we investigate the impact of graphene nanoribbons (GNRs) on the optical and electrical performance of ultra-thin SOI solar cells and compare the results with those of SOI cells incorporated with $\mathrm{Ag}$ nanostrips. Due to the extremely light confinement, high 
carrier mobility, and zero band gap characterizations, graphene is worth investigating the light absorption in the $\mathrm{Si}$ absorber layer by putting GNRs on $\mathrm{SOI}\left(\mathrm{G}_{-} \mathrm{SiO}_{2}-\right.$ $\mathrm{Si}-\mathrm{SiO}_{2}$ ) cells. Since graphene is a semimetal material, it seems that its special optical properties can help the waveguide-like modes in the optical frequency range to be strongly excited. These modes are not necessarily confined at the graphene/Si interface, but they are expanded in Si throughout. Our results show that these abnormally excitations can help the optical absorption to be increased in the active layer.

To evaluate systematically the cell's performance, the optical absorption and short-circuit current density enhancements and resistive (Ohmic) loss of $\mathrm{G}_{-} \mathrm{SiO}_{2}$-Si$\mathrm{SiO}_{2}$ solar cells are calculated and compared with those of $\mathrm{Ag}$ nanostrips incorporated $\mathrm{SOI}\left(\mathrm{Ag}-\mathrm{SiO}_{2}-\mathrm{Si}_{-} \mathrm{SiO}_{2}\right)$ cells. For $\mathrm{Ag}-\mathrm{SiO}_{2}-\mathrm{Si}-\mathrm{SiO}_{2}$ solar cells, the optimum design which has been reported previously $[17,18]$ is used. For $\mathrm{G}-\mathrm{SiO}_{2}-\mathrm{Si}-\mathrm{SiO}_{2}$ cells, width and the period of GNRs, which are two key parameters in the performance of proposed structure, are optimized.

\section{Model and theory}

The geometry of our proposed solar cell is schematically shown in Fig. 1a which comprises GNRs at the top of a SOI solar cell. A $10 \mathrm{~nm}$ buffer $\mathrm{SiO}_{2}$ layer at the bottom of GNRs prevents undesired and strong damping of the surface plasmons resonances due to the Schottky effect [2]. A $50 \mathrm{~nm}$ absorption silicon layer is located under
$\mathrm{SiO}_{2}$. Si layer is grown on a $\mathrm{SiO}_{2}$ layer with a $240 \mathrm{~nm}$ thickness. Figure $1 \mathrm{~b}$ shows a unit cell of our $\mathrm{G}-\mathrm{SiO}_{2}-\mathrm{Si}$ $\mathrm{SiO}_{2}$ solar cell. Figure 1c illustrates an $\mathrm{Ag}-\mathrm{SiO}_{2}-\mathrm{Si}-\mathrm{SiO}_{2}$ solar cell in which an $\mathrm{Ag}$ nanograting is placed at the top of a SOI solar cell. For simplicity, a unit cell is shown. Ag nanostrip has a triangle cross section with a $60 \mathrm{~nm}$ height and an $80 \mathrm{~nm}$ base. For Ag nanostrips, experimental data of Johnson and Christy [31] including the real and imaginary parts of refractive indices were utilized. For optical properties of Si layer, we have used its dielectric function given in Ref. [54]. Refractive index of $\mathrm{SiO}_{2}$ is also set to 1.45. Note that the period of G$\mathrm{SiO}_{2}-\mathrm{Si}-\mathrm{SiO}_{2}$ and $\mathrm{Ag}-\mathrm{SiO}_{2}-\mathrm{Si}-\mathrm{SiO}_{2}$ solar cells are chosen to be $314 \mathrm{~nm}$, except for Figs. 5 and $6 \mathrm{~b}$ in which the grating periods are optimized.

A plane electromagnetic wave is illuminated from the top side of the simulation frame with a normalized value of unity. To solve the Maxwell's wave equations and extraction of the solar cell parameters, we have considered only one unit cell with suitable boundary conditions to reduce the runtime and computational machine RAM. To ensure a realistic cell, we have used periodic boundary conditions for the lateral sides to include the periodicity of the structure, as shown in Fig. $1 \mathrm{~b}$ and c. We have also used a perfectly matched layer (PML) for the top and the bottom sides of the simulation frame. PML boundaries can help diffracted waves to be absorbed properly. The wavelength scan is performed from 250 to $1100 \mathrm{~nm}$ with respect to ASTM-G173 and Si band gap

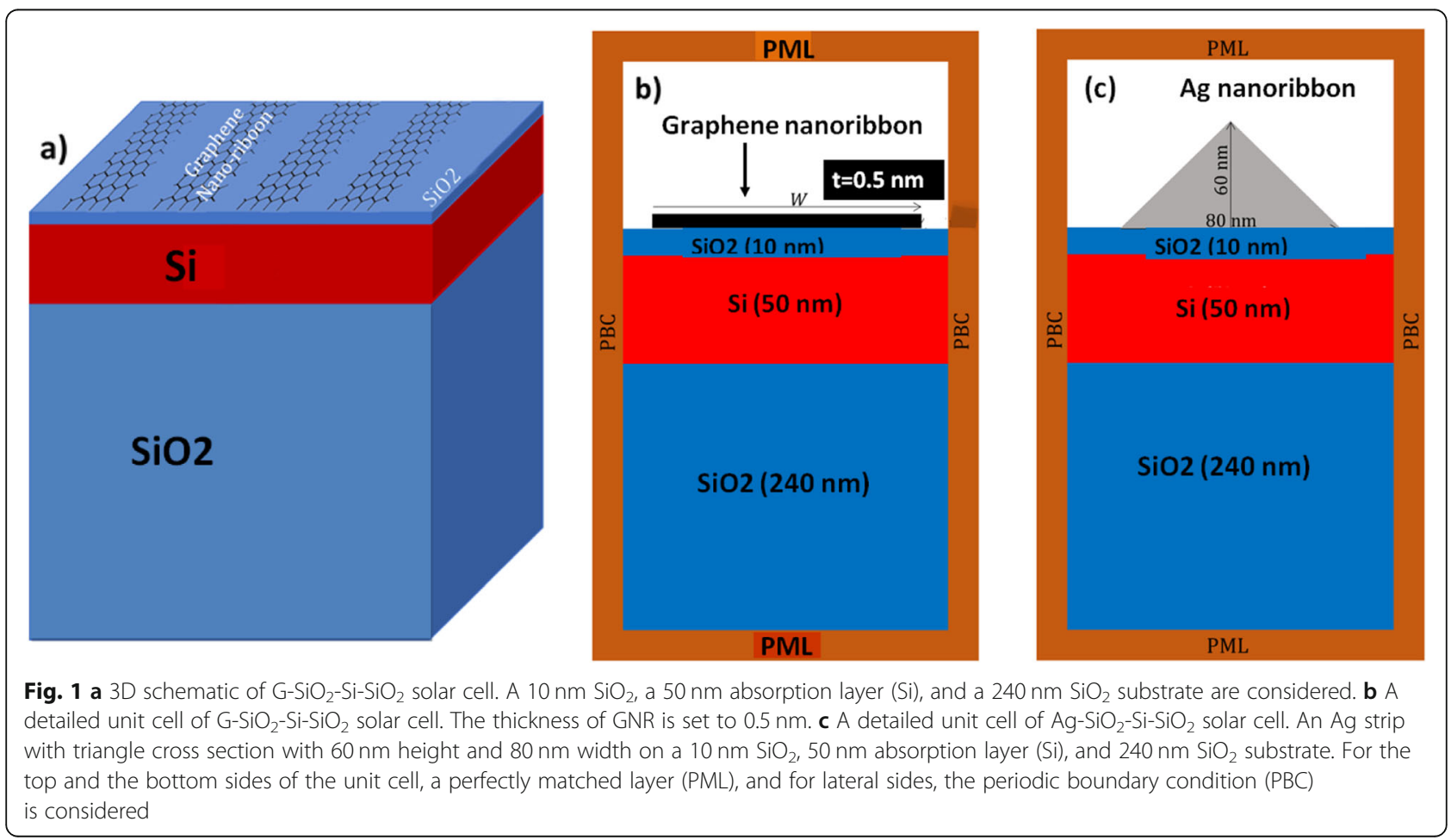


$(1.1 \mathrm{eV})$. It is worth mentioning when the imaginary part of the graphene surface conductivity is positive, the graphene layer behaves like a thin metal material and supports only transverse-magnetic (TM) mode [29]. Note also that under the transverse-electric (TE) mode, the graphene (and even $\mathrm{Ag}$ and $\mathrm{Au}$ with the thicknesses around $1 \mathrm{~nm}$ ) will not represent any electromagnetic response in the solar cell, since their thickness is much smaller than the wavelength of the incident field. Therefore, in the following, we have only focused on the TM mode. By solving the Maxwell's wave equations in the unit cell for the transverse-magnetic (TM) mode, the distribution of electric and magnetic fields was obtained. Here, the complex permittivity of graphene is calculated directly by using $\varepsilon_{g}=1-i \sigma_{g} /\left(\varepsilon_{0} \omega t\right)$ [36], where $\varepsilon_{0}$ is the permittivity of free space, $t$ is the effective thickness of the graphene, and $\sigma_{g}$ is the complex surface conductivity of graphene which depends on the angular frequency, $\omega$, chemical potential, $\mu_{c}$, temperature, $T$, and charge particle scattering rate, $\Gamma=1 / \tau$, with $\tau$ being the relaxation time of charge carriers. Regarding the intraband and interband transitions, the total conductivity of graphene $\left(\sigma_{g}=\sigma_{\text {inter }}+\sigma_{\text {intra }}\right)$ is described according to the local random phase approximation of the Kubo formula [55] which is written as [56]:

$$
\begin{aligned}
\sigma_{\text {intra }}= & \frac{2 i e^{2} T k_{B}}{\hbar^{2} \pi(\omega+i / \tau)} \ln \left[2 \cosh \left(\frac{\mu_{c}}{2 T k_{B}}\right)\right], \\
\sigma_{\text {inter }}= & \frac{e^{2}}{4 \pi}\left[\frac{1}{2}+\frac{1}{\pi} \arctan \left(\frac{\hbar \omega-2 \mu_{c}}{2 T k_{B}}\right)\right. \\
& \left.\times-\frac{i}{2 \pi} \ln \frac{\left(\hbar \omega+2 \mu_{c}\right)^{2}}{\left(\hbar \omega-2 \mu_{c}\right)^{2}+\left(2 T k_{B}\right)^{2}}\right] .
\end{aligned}
$$

In the above expression, $e$ represents the charge of the electron, $k_{B}$ is the Boltzmann's constant, and $\hbar \omega$ is the photon energy. In our calculations, we set the graphene parameters as $\tau=5 \mathrm{ps}, \mathrm{T}=300 \mathrm{~K}$, and $\mu_{c}=0.5 \mathrm{eV}$. Having found the electric and magnetic field distributions, the absorbed power in Si slab can be determined by the following formula [57]:

$$
\nabla \cdot \vec{S}=\frac{1}{2} \int_{0}^{\infty} \omega \operatorname{Im}\left(\varepsilon_{S i}\right)|E(x, y, z)|^{2} d V
$$

where $\vec{S}$ is Poynting vector, $\operatorname{Im}\left(\varepsilon_{S i}\right)$ is the imaginary part of the Si permittivity, and $d V=d x d y d y$ is the differential volume of the absorption layer (Si). According to the absorption power formula, Eq. (3), the integration is taken over the whole absorption layer volume. In our 2D modeling, the cell is assumed to be invariant along the $\mathrm{z}$ direction, so that the electromagnetic field varies only along $\mathrm{x}$ and $\mathrm{y}$. Thus $d V=l d x d y$, where $l$ is the cell length along the $\mathrm{z}$-direction.
Absorption enhancement, $\Pi(\lambda)$, is defined as the ratio of power absorbed in the Si layer of the cell with graphene nanoribbon (Ag nanostrip) to that of bare cell. Bare cells do not possess any graphene nanoribbon. Therefore, the absorption enhancement is given by:

$$
\Pi(\lambda)=\frac{\int_{\text {GNR/AG cell }}|E(x, y, \lambda)|^{2} d x d y}{\int_{\text {bare cell }}|E(x, y, \lambda)|^{2} d x d y}
$$

To perform fully evaluation on the solar cells, the short-circuit current density ( $\mathrm{J}_{\mathrm{SC}}$ ) of the proposed structures should also be calculated. $\mathrm{J}_{\mathrm{Sc}}$ is the current density flowing through the solar cell when the voltage over the cells is assumed to be zero. For an ordinary cell, the short-circuit current density is calculated through the integration of the product of solar irradiance, $I(\lambda)$, and cell spectral response, $\operatorname{SR}(\lambda)$, over the solar wavelength as: $J_{S C}=\int_{0}^{\infty} I(\lambda) \times S R(\lambda) d \lambda$. In this integration, it is assumed that the quantum efficiency is unity, $\mathrm{QE}=1$, and $\mathrm{SR}(\lambda)=$ $q \lambda / h c$, where $q$ is the elementary charge, $h$ is Planck's constant, and $c$ is the speed of light. Therefore, the $\mathrm{J}_{\mathrm{SC}}$ enhancement is given as [58]:

$$
J_{S C(\text { Enh. })}=\frac{\int_{400}^{800} I(\lambda) \times S R(\lambda) \times \prod(\lambda) d \lambda}{\int_{400}^{800} I(\lambda) \times S R(\lambda) d \lambda}
$$

where $\Pi(\lambda)$ is the absorption enhancement given by Eq. (4).

The resistive (Ohmic) loss, $\mathrm{R}_{\mathrm{L}}$, which is the solar light power converted to the heat in the cell, is an important parameter for a solar cell which, to the best of our knowledge, has not been reported yet in the solar cells decorated with plasmonic elements. Resistive loss can warm the cell through the Ohmic heat in the cell, so it restricts the cell performance. Cell heating through Ohmic loss is an undesired phenomenon which should be considered in designing the plasmonic solar cells. In order to calculate resistive loss, we integrate $\vec{J} \cdot \vec{E}(\vec{J}$ is the current density) over the GNR volume as:

$$
R_{L}=\int \vec{J} \cdot \vec{E} d V
$$

\section{Results and discussion}

In this section, we present the results of absorption enhancement, short-circuit current density enhancement, and resistive loss of $\mathrm{G}-\mathrm{SiO}_{2}-\mathrm{Si}-\mathrm{SiO}_{2}$ and $\mathrm{Ag}-\mathrm{SiO}_{2}-\mathrm{Si}$ - 
$\mathrm{SiO}_{2}$ solar cells as well as absorption enhancement of hybrid $\mathrm{Ag}-\mathrm{G}-\mathrm{SiO}_{2}-\mathrm{Si}-\mathrm{SiO}_{2}$ solar cell. In all schemes, the thickness of the absorption layer $(\mathrm{Si})$ is taken to be the same.

Figure 2 shows the effect of GNR width (W) on the absorption enhancement of $\mathrm{G}-\mathrm{SiO}_{2}-\mathrm{Si}-\mathrm{SiO}_{2}$ solar cell. To compare the results with those of $\mathrm{Ag}-\mathrm{SiO}_{2}-\mathrm{Si}_{-}-\mathrm{SiO}_{2}$ one, we have also plotted the absorption enhancement of $\mathrm{Ag}-\mathrm{SiO}_{2}-\mathrm{Si}-\mathrm{SiO}_{2}$ solar cell in this figure. It is seen that the absorption enhancement of $\mathrm{G}-\mathrm{SiO}_{2}-\mathrm{Si}-\mathrm{SiO}_{2}$ cell strongly depends on the GNR width. For example, as W is increased from 150 to $250 \mathrm{~nm}$, the absorption enhancement increases, too. If $\mathrm{W}$ is increased further to $280 \mathrm{~nm}$, the absorption enhancement reduces drastically. Therefore, in the rest of this paper, we choose $\mathrm{W}=250$ $\mathrm{nm}$ as the optimum value for GNR width. It is interesting to note that for $\mathrm{W}=250 \mathrm{~nm}$, the absorption enhancement has a sharp peak around $508 \mathrm{~nm}$ (blue curve in Fig. 2.). This peak is related to the waveguide mode which is excited in Si layer. Figure 3a, which shows the normalized magnetic field distribution, clearly illustrates this mode happens at $508 \mathrm{~nm}$.

As the blue curve in Fig. 2 shows, the absorption enhancement in $\mathrm{Si}$ layer is much stronger than that of Ag$\mathrm{SiO}_{2}-\mathrm{Si}-\mathrm{SiO}_{2}$ cell which happens at $508 \mathrm{~nm}$. From the magnetic field distribution, Fig. 3c, for $\mathrm{Ag}-\mathrm{SiO}_{2}-\mathrm{Si}-\mathrm{SiO}_{2}$ cell, one can conclude that there is no enhanced optical near field for absorption enhancement, because this wavelength is far from the plasmonic resonance wavelength. Interestingly, at this wavelength, the magnetic field is strongly confined and enhanced in the $\mathrm{G}-\mathrm{SiO}_{2}$ $\mathrm{Si}-\mathrm{SiO}_{2}$ cell (see Fig. 3a). Therefore, due to the special transport properties of graphene, the light energy

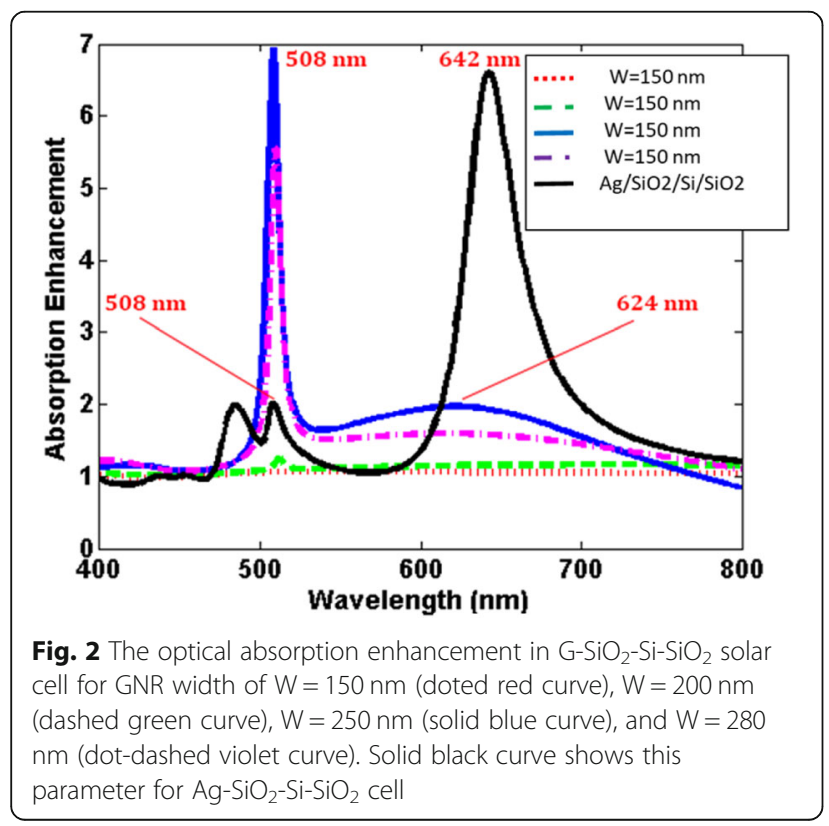

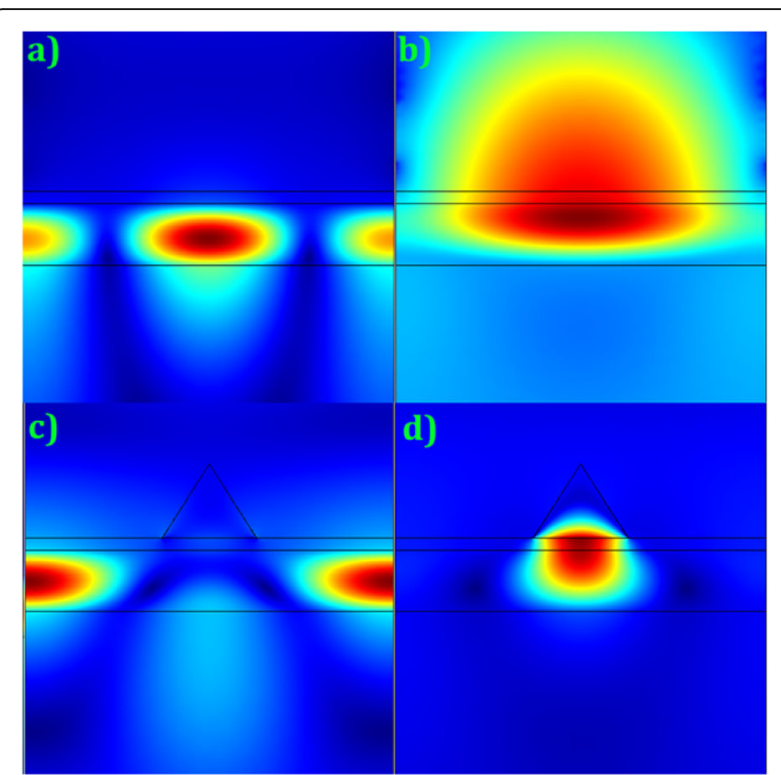

Fig. 3 Distribution of normalized magnetic field: $\mathbf{a}$ and $\mathbf{b}$ are the waveguide and plasmonic-like modes of $\mathrm{G}-\mathrm{SiO}_{2}-\mathrm{Si}_{-}-\mathrm{SiO}_{2}$ solar cell corresponding to 508 and $624 \mathrm{~nm}$, respectively, c and $\mathbf{d}$ are the waveguide and plasmonic modes of $\mathrm{Ag}-\mathrm{SiO}_{2}-\mathrm{Si}-\mathrm{SiO}_{2}$ solar cell corresponding to 508 and $642 \mathrm{~nm}$, respectively

concentration and near field enhancement occur in the silicon layer. In the visible range, there are also other modes for $\mathrm{G}_{-} \mathrm{SiO}_{2}-\mathrm{Si}-\mathrm{SiO}_{2}$ cell happening at $624 \mathrm{~nm}$ and for $\mathrm{Ag}-\mathrm{SiO}_{2}-\mathrm{Si}-\mathrm{SiO}_{2}$ happening at $642 \mathrm{~nm}$, which assist in solar light absorption in $\mathrm{Si}$ layer. For $\mathrm{G}-\mathrm{SiO}_{2}-\mathrm{Si}-\mathrm{SiO}_{2}$ cell, we call it plasmonic-like mode, because for graphene, the plasmonic modes excite at Mid-IR or terahertz spectrum region [28]. For $\mathrm{Ag}-\mathrm{SiO}_{2}-\mathrm{Si}-\mathrm{SiO}_{2}$ cell, it is definitly a localized surface plasmonic (LSP) mode, which occurs at $642 \mathrm{~nm}$ and is illustrated clearly in Fig. $3 \mathrm{~d}$. Although due to the plasmonic mode excitation for $\mathrm{Ag}-\mathrm{SiO}_{2}-\mathrm{Si}-\mathrm{SiO}_{2}$ cell at $642 \mathrm{~nm}$, the absorption enhancement is much higher than that of $\mathrm{G}-\mathrm{SiO}_{2}-\mathrm{Si}-\mathrm{SiO}_{2}$ cell mode at $624 \mathrm{~nm}$, the latter has an enahncement over a wider range of wavelengths (see Fig. 2). For instance, by increasing the wavelength from $510 \mathrm{~nm}$ to $600 \mathrm{~nm}$, the absorption enhancement of the $\mathrm{Ag}-\mathrm{SiO}_{2}-\mathrm{Si}-\mathrm{SiO}_{2}$ cell drops down to 1 , but for $\mathrm{G}-\mathrm{SiO}_{2}-\mathrm{Si}-\mathrm{SiO}_{2}$ cell, it changes from 1.5 to 1.85 . This charactristic will be much more effective in the future calculations for quantities such as short-circuit current density.

In order to enhance even more the light-graphene interaction [50], we have designed a hybrid solar cell by placing GNR between $\mathrm{Ag}$ nanostrip and the SOI substrate $\left(\mathrm{Ag}-\mathrm{G}-\mathrm{SiO}_{2}-\mathrm{Si}-\mathrm{SiO}_{2}\right)$, as is schematically shown in the Fig. 4a. Figure $4 \mathrm{~b}$ represents the absorption enhancement of the proposed hybrid $\mathrm{Ag}-\mathrm{G}-\mathrm{SiO}_{2}-\mathrm{Si}-\mathrm{SiO}_{2}$ cell, where different heights of 10, 40, and $60 \mathrm{~nm}$ for $\mathrm{Ag}$ nanostrips were considered. For comparison, in Fig. 4b, 

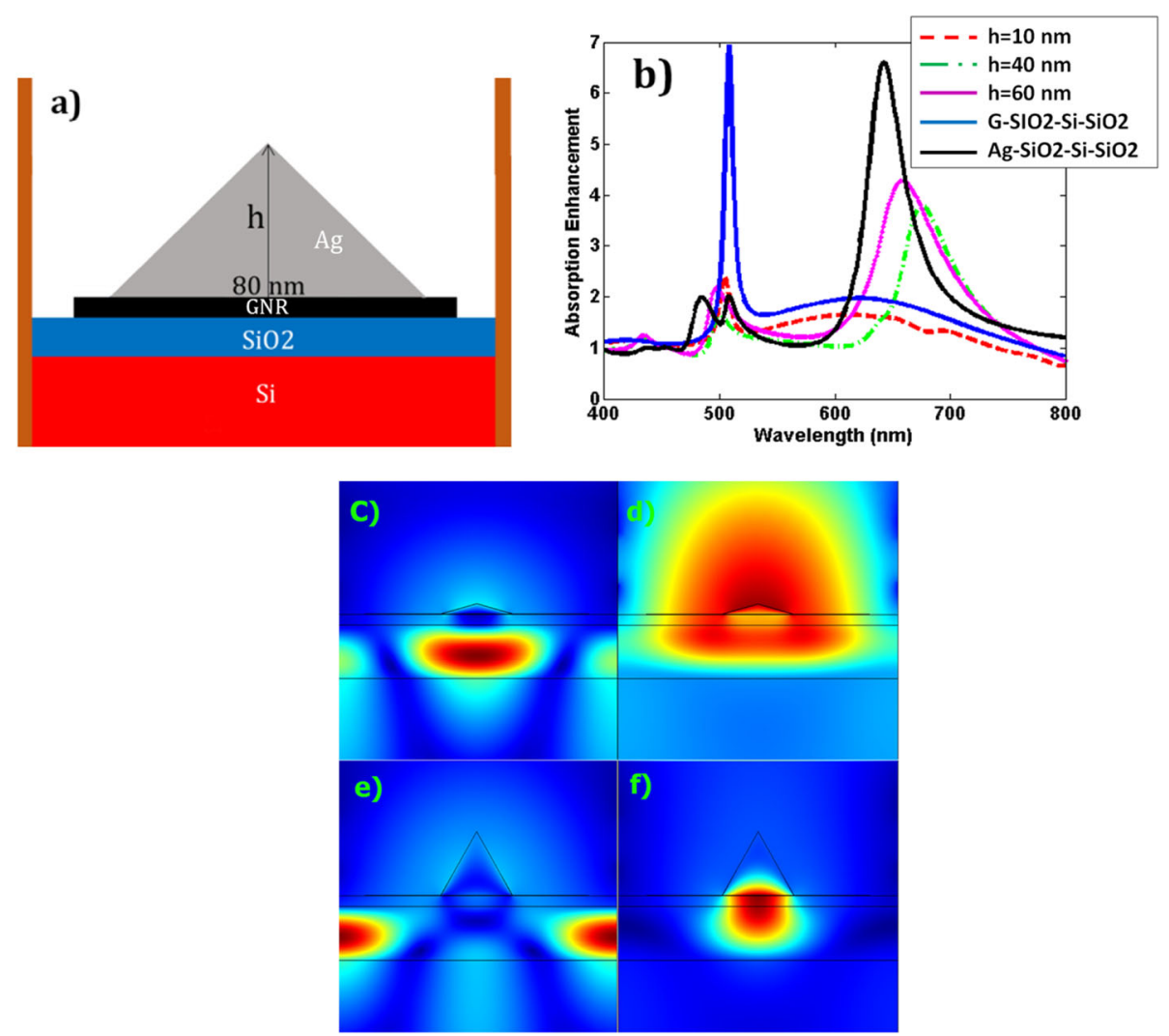

Fig. 4 a Detailed structure of a hybrid $\mathrm{Ag}-\mathrm{G}-\mathrm{SiO}_{2}-\mathrm{Si}-\mathrm{SiO}_{2}$ cell including GNR with $0.5 \mathrm{~nm}$ height and $\mathrm{W}=250 \mathrm{~nm}$ width and the Ag nanostrip with $80 \mathrm{~nm}$ base length and variable heights of $\mathrm{h}=10,40$, and $60 \mathrm{~nm}$. b The absorption enhancements of the hybrid cell for $\mathrm{h}=10 \mathrm{~nm}$ (dashed red curve), $40 \mathrm{~nm}$ (dot dashed green curve), and $60 \mathrm{~nm}$ (solid doted violet curve) in comparison with a cell comprising solely a $\mathrm{G}-\mathrm{SiO}_{2}-\mathrm{Si}_{-}-\mathrm{SiO}_{2}$ cell (solid blue curve) and $\mathrm{Ag}_{-} \mathrm{SiO}_{2}-\mathrm{Si}_{-} \mathrm{SiO}_{2}$ cell (solid black curve). Distribution of the normalized magnetic field of hybrid cell with $\mathrm{h}=10 \mathrm{~nm}$ at (c) $506 \mathrm{~nm}$ and (d) 620, and $\mathrm{h}=60 \mathrm{~nm}$ at (e) $497 \mathrm{~nm}$ and (f) $659 \mathrm{~nm}$

we have also shown the results for solely $\mathrm{G}-\mathrm{SiO}_{2}$-Si$\mathrm{SiO}_{2}$ and $\mathrm{Ag}-\mathrm{SiO}_{2}-\mathrm{Si}-\mathrm{SiO}_{2}$ solar cells. It is found that for an $\mathrm{Ag}-\mathrm{SiO}_{2}-\mathrm{Si}-\mathrm{SiO}_{2}$ cell with a $10 \mathrm{~nm}$ height, there is only a single waveguide peak at $506 \mathrm{~nm}$ with a 2.2 enhancement in optical absorption. The magnetic field distribution of this mode is shown in Fig. 4c. From the field distribution, it is observed that the electromagnetic field is strongly confined in the $\mathrm{Si}$ layer. For this height, there is a very wide peak for optical absorption in the longer wavelengths region, where we have not shown its distribution. As the height of the $\mathrm{Ag}$ nanostrip is increased (i.e. when reach $\mathrm{h}=40 \mathrm{~nm}$ and $60 \mathrm{~nm}$ ) the absorption enhancement corresponding to the plasmonic mode is arisen. From Fig. 4b we observe that for $\mathrm{h}=40$ and $60 \mathrm{~nm}$ for $\mathrm{Ag}$ height, an enhancement of 4.5 and 3.8 is observed for plasmonic mode at $659 \mathrm{~nm}$ and $667 \mathrm{~nm}$, respectively (violet and dashed green curves in Fig. 4b). Figure $4 \mathrm{~d}$, e, and $\mathrm{f}$ show normalized magnetic distributions for hybrid solar cell with an Ag nanostrip with the height of $\mathrm{h}=10 \mathrm{~nm}$ at (c) $506 \mathrm{~nm}$ and (d) $620 \mathrm{~nm}$, and $\mathrm{h}=60 \mathrm{~nm}$ at (e) $497 \mathrm{~nm}$ and (f) $659 \mathrm{~nm}$.
In the following, we optimize the cell's performance with considering the period of the GNRs and Ag nanostrips. Figure $5 \mathrm{a}$ shows the results for optical absorption of $\mathrm{G}-\mathrm{SiO}_{2}-\mathrm{Si}_{-} \mathrm{SiO}_{2}$ cell for different periods. It is observed that by increasing the period of GNRs from 300 $\mathrm{nm}$, the optical absorption is increased. Also, the absorption peaks are shifted toward longer wavelengths. Our calculations show that the optimum period is around $358 \mathrm{~nm}$. Precisely, the $\mathrm{G}-\mathrm{SiO}_{2}-\mathrm{Si}-\mathrm{SiO}_{2}$ solar cell has a peak for optical absorption enhancement at $500 \mathrm{~nm}$ with magnitude of 5.67 for $P=300 \mathrm{~nm}$ which increases up to 18.37 at $540 \mathrm{~nm}$ for $P=358 \mathrm{~nm}$.

From Fig. 5b we observe that the period of the Ag$\mathrm{SiO}_{2}-\mathrm{Si}-\mathrm{SiO}_{2}$ cell has more impact on enhancing the optical absorption through waveguide mode rather than plasmonics mode. It is seen that for $\mathrm{P}=300 \mathrm{~nm}$, the absorption enhancement corresponding to the waveguide and plasmonic modes occurs at $480 \mathrm{~nm}$ and $641 \mathrm{~nm}$ with the value of 2.10 and 6.18 , respectively. For $P=358 \mathrm{~nm}$, these peaks shift to $537 \mathrm{~nm}$ and $654 \mathrm{~nm}$ with magnitude of 4.95 and 7.42, respectively. From Fig. 5 a and b, one can conclude that for $\mathrm{P}=358 \mathrm{~nm}$, the absorption 

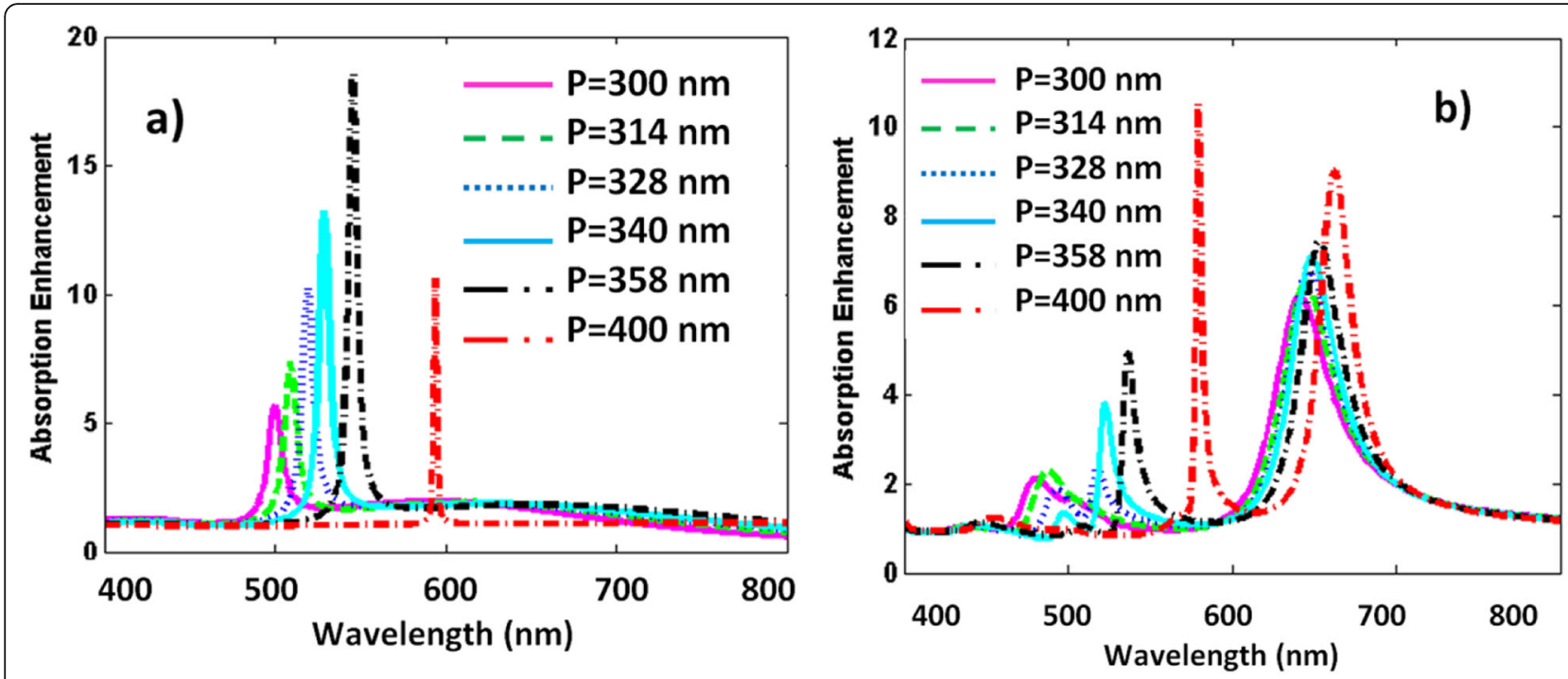

Fig. 5 Absorption enhancement of $\mathbf{a} \mathrm{G}-\mathrm{SiO}_{2}-\mathrm{Si}-\mathrm{SiO}$ and $\mathbf{b} \mathrm{Ag}-\mathrm{SiO}_{2}-\mathrm{Si}-\mathrm{SiO}_{2}$ solar cells for different periods; $P=300 \mathrm{~nm}$ (solid violet curve), $P=314$ $\mathrm{nm}$ (dashed green curve), $P=328 \mathrm{~nm}$ (dotted blue curve), $P=340 \mathrm{~nm}$ (solid cyan curve), $P=358 \mathrm{~nm}$ (dot-dashed black curve), and $P=400 \mathrm{~nm}$ (dot-dashed red curve)

enhancement for waveguide modes of the $\mathrm{G}_{-} \mathrm{SiO}_{2}-\mathrm{Si}$ $\mathrm{SiO}_{2}$ cell is much higher than that of the $\mathrm{Ag}-\mathrm{SiO}_{2}-\mathrm{Si}-$ $\mathrm{SiO}_{2}$ cell. However, as it has been discussed earlier, $\mathrm{Ag}$ solar cells lead to an increase in optical absorption by their localized surface plasmons (LSP). Therefore, increasing the period of Ag nanograting helps better absorption of incident light due to its multiple peaks, proportional to their LSP modes. However, it is very crucial issue whether or not this absorbed power would cause a stronger short-circuit current density. In this regard, and in order to compare the performance of G$\mathrm{SiO}_{2}-\mathrm{Si}_{-}-\mathrm{SiO}_{2}$ and $\mathrm{Ag}-\mathrm{SiO}_{2}-\mathrm{Si}-\mathrm{SiO}{ }_{2}$ cells, we have emphasized $\mathrm{J}_{\mathrm{SC}}$ enhancement, which is the ratio of $\mathrm{J}_{\mathrm{SC}}$ of the cell with nanostrip (nanoribbon) divided to $\mathrm{I}_{\mathrm{SC}}$ of the bare cell without nanostrip (nanoribbon).

Figure $6 \mathrm{a}$ and $\mathrm{b}$ show the short-circuit current density $\left(\mathrm{J}_{\mathrm{sc}}\right)$ enhancement for $\mathrm{G}-\mathrm{SiO}_{2}-\mathrm{Si}-\mathrm{SiO}_{2}$ and $\mathrm{Ag}-\mathrm{SiO}_{2}-\mathrm{Si}$ $\mathrm{SiO}_{2}$ solar cells, respectively. In Fig. 6a, we have evaluated the $J_{\mathrm{sc}}$ for various widths of GNRs, where, as we expected, $W=250 \mathrm{~nm}$ gives the optimum value. In Fig. $6 \mathrm{~b}$

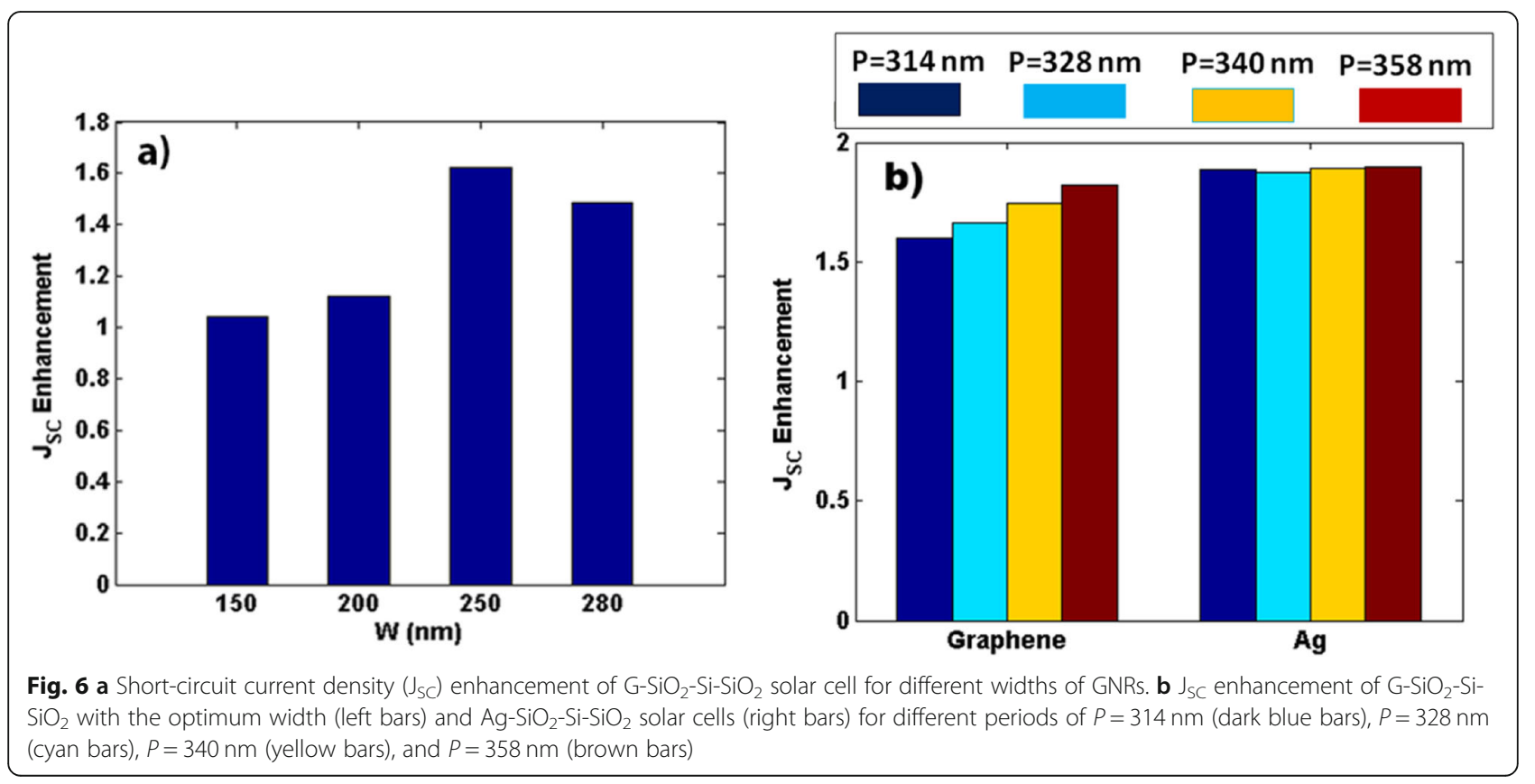


we have compared the results of period optimizations of both $\mathrm{G}_{-}-\mathrm{SiO}_{2}-\mathrm{Si}-\mathrm{SiO}_{2}$ with $\mathrm{W}=250 \mathrm{~nm}$ and $\mathrm{Ag}-\mathrm{SiO}_{2}-\mathrm{Si}$ $\mathrm{SiO}_{2}$ cells. It is seen that as the period is increased, the $\mathrm{J}_{\mathrm{sc}}$ for $\mathrm{G}-\mathrm{SiO}_{2}-\mathrm{Si}-\mathrm{SiO}_{2}$ cell also increases. As expected, $P=358 \mathrm{~nm}$ is the optimum period for $\mathrm{J}_{\mathrm{sc}}$ of $\mathrm{G}_{-} \mathrm{SiO}_{2}-\mathrm{Si}-$ $\mathrm{SiO}_{2}$ solar cell. However, for $\mathrm{Ag}-\mathrm{SiO}_{2}-\mathrm{Si}-\mathrm{SiO}_{2}$ solar cell, various periods (in the range of 314 to $358 \mathrm{~nm}$ ) give almost the same $\mathrm{J}_{\mathrm{sc}}$. Interestingly, for $\mathrm{G}-\mathrm{SiO}_{2}-\mathrm{Si}-\mathrm{SiO}_{2}$ solar cell with $P=358 \mathrm{~nm}$, two types of cells give more and less the same value.

The last important quantity which has been investigated in this work as the highlight prospect is the resistive (Ohmic) loss. This quantity says about an undesired phenomenon which is the main factor of dissipation of useful energy absorbed from the sunlight. To make a comparison, we have calculated the ratio of absorbed power in the GNRs/Ag nanograting layer to the total sunlight power radiated to the cell. We call it as normalized resistive loss $\left(\mathrm{R}_{\mathrm{L}}\right)$. Figure 7 depicts the normalized resistive loss as a function of wavelength for $\mathrm{Ag}-\mathrm{SiO}_{2}-\mathrm{Si}$ $\mathrm{SiO}_{2}$ (dashed red curve) and $\mathrm{G}-\mathrm{SiO}_{2}-\mathrm{Si}-\mathrm{SiO}_{2}$ solar cells (solid blue curve) in the visible frequency range. It can be observed that the normalized loss of the $\mathrm{G}-\mathrm{SiO}_{2}-\mathrm{Si}$ $\mathrm{SiO}_{2}$ is much lower than that of the $\mathrm{Ag}-\mathrm{SiO}_{2}-\mathrm{Si}-\mathrm{SiO}_{2}$. It is found that $\mathrm{G}-\mathrm{SiO}_{2}-\mathrm{Si}-\mathrm{SiO}_{2}$ dissipates at most $4.7 \%$ of the incident power which happens at $508 \mathrm{~nm}$, but $\mathrm{Ag}$ $\mathrm{SiO}_{2}-\mathrm{Si}-\mathrm{SiO}_{2}$ generally dissipates much higher solar energy entire the solar spectrum. For instance, at $480 \mathrm{~nm}$ and $637 \mathrm{~nm}, \mathrm{Ag}-\mathrm{SiO}_{2}-\mathrm{Si}-\mathrm{SiO}_{2}$ dissipates, respectively, up to $29 \%$ and $24 \%$ of the incident power. This portion naturally is converted to the heat. The very low amount of dissipation for $\mathrm{G}-\mathrm{SiO}_{2}-\mathrm{Si}-\mathrm{SiO}_{2}$ cell is an invaluable point, because heating the solar cell actually reduces the cell's performance. Therefore, it is safe to say that in the meantime that $\mathrm{G}-\mathrm{SiO}_{2}-\mathrm{Si}-\mathrm{SiO}_{2}$ and $\mathrm{Ag}-\mathrm{SiO}_{2}-\mathrm{Si}-\mathrm{SiO}_{2}$ enhance the solar cell's electric and optical performance

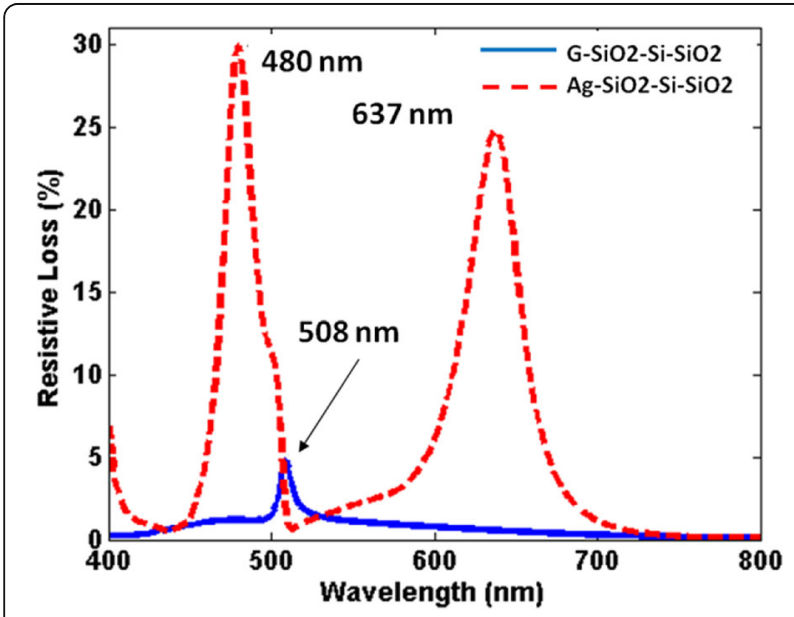

Fig. 7 The resistive loss of $\mathrm{G}_{-} \mathrm{SiO}_{2}-\mathrm{Si}-\mathrm{SiO}_{2}$ (solid blue curve) and Ag$\mathrm{SiO}_{2}-\mathrm{Si}_{-} \mathrm{SiO}_{2}$ (dashed red curve) solar cells with the same values, GNRs impose noticeably lower energy dissipation in the cell, so it is a better candidate for incorporating in photovoltaic ultra-thin cells. Recently, several experiments have shown that the chemical vapor deposition (CVD) graphene can be used to improve the performance of the solar cells $[59,60]$. Indeed, CVD is the primary technique used to obtain large-area graphene sheets, which are usually in high demand for various solar cell applications. In these experiments, the graphene was synthesized on a $\mathrm{Cu}$ foil by an atmospheric pressure CVD (APCVD) and then transferred to a glass substrate. The number of graphene layers could be well controlled via altering the $\mathrm{H}_{2}$ flow rate, which also provides a wide selection range of transparency and sheet resistance. In order to provide a better coverage and contact on $\mathrm{CdTe}$ solar cell, the graphene was synthesized with a threedimensional (3D) structure using porous $\mathrm{Ni}$ foam as the growth substrate. A similar method was employed to grow graphene and the 3D structure was successfully observed and transferred to CdTe device [61]. The final graphene back contact thickness exceeded $10 \mu \mathrm{m}$ with an excellent electrical conductivity (550-600 S/cm), which assisted a significant device efficiency improvement up to $9.1 \%$.

\section{Conclusion}

In summary, we have numerically studied the optical absorption and short-circuit current density enhancements and resistive loss of $\mathrm{G}-\mathrm{SiO}_{2}-\mathrm{Si}-\mathrm{SiO}_{2}$ and $\mathrm{Ag}-\mathrm{SiO}_{2}-\mathrm{Si}-$ $\mathrm{SiO}_{2}$ solar cells which are SOI solar cells with, respectively, GNR and Ag nanogratings at the top. We have compared the results of both cells in the visible frequency range. It is found that the performance of the G$\mathrm{SiO}_{2}-\mathrm{Si}-\mathrm{SiO}_{2}$ solar cell strongly depends on the width (W) of GNRs and the period (P) of the structure. By optimizing the $\mathrm{W}$ and $\mathrm{P}$ of the $\mathrm{G}-\mathrm{SiO}_{2}-\mathrm{Si}-\mathrm{SiO}_{2}$ cell, we could achieve the maximum absorption enhancement for GNR solar cell $(18.37$ at $540 \mathrm{~nm})$ which is three times higher than that of $\mathrm{Ag}$ solar cell at this wavelength. It is demonstrated that the GNR cells with optimum $\mathrm{W}$ and $\mathrm{P}$ can intensify the waveguide mode peak and cause a better confining of the light into the Si layer. However, Ag solar cell has strong absorption enhancement due to conducting the light into the $\mathrm{Si}$ layer by its localized surface plasmons (LSP) modes. The result of calculating short-circuit current density enhancement confirmed that the GNR solar cell with optimized $\mathrm{W}$ and $\mathrm{P}$ can intensify the waveguide modes high enough such that having a same $\mathrm{J}_{\mathrm{SC}}$ enhancement compared to Ag solar cell, despite their lack of plasmonic behavior in this frequency range. The outstanding point of this work is the low resistive loss of GNR solar cells. Our 
calculations showed that GNR solar cells dissipate only less than $5 \%$ of incident sunlight power inside the SOI cell happening at $508 \mathrm{~nm}$, compared to high values for Ag solar cells which dissipate the solar power up to $29 \%$ and $24 \%$ happening at, respectively, 480 and $637 \mathrm{~nm}$.

\section{Acknowledgements}

M. S. and Y. H. would like to thank SCU of Ahvaz for financial supporting this work.

\section{Authors' contributions}

M.S. has defined the subject of the article and simulated the problem. Y.H. has written the manuscript, checked the results and made full discussion. The author(s) read and approved the final manuscript.

\section{Authors' information}

M.S. is an associate professor of physics in optics and laser at SCU and is currently the manager of Center for Research on Laser and Plasma (CRLP). His research interest is nanophotonic and light-matter interaction. $\mathrm{Y} . \mathrm{H}$. is an assistance professor of physics in condensed matter and is a member of CRLP of SCU. His main interest is optical and electrical properties of two-dimensional materials.

\section{Funding}

This work has been supported by Deputy of Research and Technology of Shahid Chamran University (SCU) of Ahvaz under the grant number of SCUSP98.259.

\section{Availability of data and materials}

The datasets used and/or analysed during the current study are available from the corresponding author on reasonable request.

\section{Competing interests}

The authors declare that they have no competing interests.

\section{Received: 3 March 2020 Accepted: 8 June 2020}

\section{Published online: 16 June 2020}

\section{References}

1. Ferry, V.E., Munday, J.N., Atwater, H.A.: Design considerations for plasmonic photovoltaics. Adv. Mater. 22, 4794-4808 (2010)

2. Pala, R.A., White, J., Barnard, E., Liu, J., Brongersma, M.L.: Design of plasmonic thin-film solar cells with broadband absorption enhancements. Adv. Mater. 21, 3504-3509 (2009)

3. Zhou, D., Biswas, R.: Photonic crystal enhanced light-trapping in thin film solar cells. J. Appl. Phys. 103, 093102 (2008)

4. Atwater, H.A., Polman, A.: Plasmonics for improved photovoltaic devices. Nat. Mater. 9, 205-213 (2010)

5. Pillai, S., Green, M.: Plasmonics for photovoltaic applications. Sol. Energy Mater. Sol. Cells. 94, 1481-1486 (2010)

6. Redfield, D.: Multiple-pass thin-film silicon solar cell. Appl. Phys. Lett. 25 647-648 (1974)

7. Yablonovitch, E.: Statistical ray optics. JOSA. 72, 899-907 (1982)

8. Ou, Q., Zhang, Y., Wang, Z., Yuwono, J.A., Wang, R., Dai, Z., et al.: Strong depletion in hybrid perovskite $\mathrm{p}-\mathrm{n}$ junctions induced by local electronic doping. Adv. Mater. 30, 1705792 (2018)

9. Chen, K., Jin, W., Zhang, Y., Yang, T., Reiss, P., Zhong, Q., et al.: High efficiency mesoscopic solar cells using CsPbl3 perovskite quantum dots enabled by chemical interface engineering. J. Am. Chem. Soc. 142, 3775-3783 (2020)

10. Chen, K., Zhong, Q., Chen, W., Sang, B., Wang, Y., Yang, T., et al.: Short-chain ligand-passivated stable a-CsPbl3 quantum dot for all-inorganic perovskite solar cells. Adv. Funct. Mater. 29, 1900991 (2019)

11. Biswas, R., Xu, C.: Nano-crystalline silicon solar cell architecture with absorption at the classical 4n 2 limit. Opt. Express. 19, A664-A672 (2011)

12. Munday, J.N., Atwater, H.A.: Large integrated absorption enhancement in plasmonic solar cells by combining metallic gratings and antireflection coatings. Nano Lett. 11, 2195-2201 (2010)
13. Kim, S.-S., Na, S.-I., Jo, J., Kim, D.-Y., Nah, Y.-C.: Plasmon enhanced performance of organic solar cells using electrodeposited Ag nanoparticles. Appl. Phys. Lett. 93, 305 (2008)

14. Catchpole, K.. Polman, A.: Design principles for particle plasmon enhanced solar cells. Appl. Phys. Lett. 93, 191113 (2008)

15. Standridge, S.D., Schatz, G.C., Hupp, J.T.: Toward plasmonic solar cells: protection of silver nanoparticles via atomic layer deposition of $\mathrm{TiO} 2$. Langmuir. 25, 2596-2600 (2009)

16. Moreno, F., García-Cámara, B., Saiz, J., González, F.: Interaction of nanoparticles with substrates: effects on the dipolar behaviour of the particles. Opt. Express. 16, 12487-12504 (2008)

17. Heydari, M., Sabaeian, M.: Plasmonic nanogratings on MIM and SOI thin-film solar cells: comparison and optimization of optical and electric enhancements. Appl. Opt. 56, 1917-1924 (2017)

18. Sabaeian, M., Heydari, M., Ajamgard, N.: Plasmonic excitation-assisted optical and electric enhancement in ultra-thin solar cells: the influence of nanostrip cross section. AlP Adv. 5, 087126 (2015)

19. Zhang, Y., Lim, C.-K., Dai, Z., Yu, G., Haus, J.W., Zhang, H., et al.: Photonics and optoelectronics using nano-structured hybrid perovskite media and their optical cavities. Phys. Rep. 795,1-51(2019)

20. Gao, T., Stevens, E., Lee, J.-k., Leu, P.W.: Designing metal hemispheres on silicon ultrathin film solar cells for plasmonic light trapping. Opt. Lett. 39, 4647-4650 (2014)

21. Karatay, D.U., Salvador, M., Yao, K., Jen, A.K.-Y., Ginger, D.S.: Performance limits of plasmon-enhanced organic photovoltaics. Appl. Phys. Lett. 105 109-101 (2014)

22. Pillai, S., Catchpole, K., Trupke, T., Green, M.: Surface plasmon enhanced silicon solar cells. J. Appl. Phys. 101, 093105 (2007)

23. Lin, M.-Y., Kang, Y.L., Chen, Y.-C., Tsai, T.-H., Lin, S.-C., Huang, Y.-H., et al.: Plasmonic ITO-free polymer solar cell. Opt. Express. 22, A438-A445 (2014)

24. Lee, S., Mason, D.R., In, S., Park, N.: Embedding metal electrodes in thick active layers for ITO-free plasmonic organic solar cells with improved performance. Opt. Express. 22, A1145-A1152 (2014)

25. Hsiao, $H-H_{1}$ Chang, H-C., Wu, Y.-R: Design of anti-ring back reflectors for thin-film solar cells based on three-dimensional optical and electrical modeling. Appl. Phys. Lett. 105, 061108 (2014)

26. Zhang, Y., Jia, B., Ouyang, Z., Gu, M.: Influence of rear located silver nanoparticle induced light losses on the light trapping of silicon waferbased solar cells. J. Appl. Phys. 116, 124303 (2014)

27. Morawiec, S., Mendes, M.J., Filonovich, S.A., Mateus, T., Mirabella, S., Áquas, H. , et al.: Broadband photocurrent enhancement in a-Si: $\mathrm{H}$ solar cells with plasmonic back reflectors. Opt. Express. 22, A1059-A1070 (2014)

28. You, J., Li, X., Xie, F.X., Sha, W.E., Kwong, J.H., Li, G., et al.: Surface Plasmon and Scattering-Enhanced Low-Bandgap Polymer Solar Cell by a Metal Grating Back Electrode. Adv. Energy Mater. 2, 1203-1207 (2012)

29. West, P.R., Ishii, S., Naik, G.V., Emani, N.K., Shalaev, V.M., Boltasseva, A.: Searching for better plasmonic materials. Laser Photonics Rev. 4, 795-808 (2010)

30. Heidari, M., Sabaeian, M., Ajamgard, N.: The influence of silver nanopyramids on the optical absorption in the plasmonic organic photovoltaic cells. J. Res. Many-body Syst. 6, 63-70 (2016)

31. Johnson, P.B., Christy, R.-W.: Optical constants of the noble metals. Phys. Rev. B. $6,4370(1972)$

32. Pei, J., Yang, J., Yildirim, T., Zhang, H., Lu, Y.: Many-body complexes in $2 \mathrm{D}$ semiconductors. Adv. Mater. 31, 1706945 (2019)

33. Guo, S., Zhang, Y., Ge, Y., Zhang, S., Zeng, H., Zhang, H.: 2D V-V binary materials: status and challenges. Adv. Mater. 31, 1902352 (2019)

34. He, J., Tao, L., Zhang, H., Zhou, B., Li, J.: Emerging 2D materials beyond graphene for ultrashort pulse generation in fiber lasers. Nanoscale. 11 2577-2593 (2019)

35. Shalaev, V.M.: Transforming light. Science. 322(5900),384-386 (2008)

36. Vakil, A., Engheta, N.: Transformation optics using graphene. Science. 332, 1291-1294 (2011)

37. Jablan, M., Buljan, H., Soljačić, M.: Plasmonics in graphene at infrared frequencies. Phys. Rev. B. 80, 245435 (2009)

38. Koppens, F.H., Chang, D.E., García de Abajo, F.J.: Graphene plasmonics: a platform for strong light-matter interactions. Nano Lett. 11, 3370-3377 (2011)

39. Hajati, Y., Zanbouri, Z., Sabaeian, M.: Low-loss and high-performance midinfrared plasmon-phonon in graphene-hexagonal boron nitride waveguide. JOSA B. 35, 446-453 (2018) 
40. Hajati, Y., Zanbouri, Z., Sabaeian, M.: Optimizing encapsulated graphene in hexagonal boron nitride toward low propagation loss and enhanced field confinement. JOSA B. 36, 1189-1199 (2019)

41. Zhou, X., Zhang, T., Chen, L., Hong, W., Li, X.: A graphene-based hybrid plasmonic waveguide with ultra-deep subwavelength confinement. J. Lightwave Technol. 32, 3597-3601 (2014)

42. Novoselov, K.S., Geim, A.K., Morozov, S.V., Jiang, D., Zhang, Y., Dubonos, S.V., et al.: Electric field effect in atomically thin carbon films. Science. 306, 666669 (2004)

43. Novoselov, K.S., Geim, A.K., Morozov, S., Jiang, D., Katsnelson, M., Grigorieva, I., et al.: Two-dimensional gas of massless Dirac fermions in graphene. Nature. 438, 197-200 (2005)

44. Geim, A.K., Novoselov, K.S.: The rise of graphene. Nat. Mater. 6, 183-191 (2007)

45. Bonaccorso, F., Sun, Z., Hasan, T., Ferrari, A.: Graphene photonics and optoelectronics. Nat. Photonics. 4, 611-622 (2010)

46. Avouris, P.: Graphene: electronic and photonic properties and devices. Nano Lett. 10, 4285-4294 (2010)

47. Avouris, P., Freitag, M.: Graphene photonics, plasmonics, and optoelectronics. IEEE J. Selected Topics Quantum Electron. 20, $72-83$ (2014)

48. Garcia de Abajo, F.J: Graphene plasmonics: challenges and opportunities. Acs Photonics. 1, 135-152 (2014)

49. Hanson, G.W.: Dyadic Green's functions and guided surface waves for a surface conductivity model of graphene. J. Appl. Phys. 103, 064302 (2008)

50. Hajati, M., Hajati, Y.: Dynamic tuning of mid-infrared plasmons in graphenebuffer-SiO 2-Si nanostructures. JOSA B. 33, 1303-1310 (2016)

51. Hajati, M., Hajati, Y.: High-performance and low-loss plasmon waveguiding in graphene-coated nanowire with substrate. JOSA B. 33, 2560-2565 (2016)

52. Christensen, J., Manjavacas, A., Thongrattanasiri, S., Koppens, F.H., García de Abajo, F.J: Graphene plasmon waveguiding and hybridization in individual and paired nanoribbons. ACS Nano. 6, 431-440 (2011)

53. Patel, K., Tyagi, P.K.: Multilayer graphene as a transparent conducting electrode in silicon heterojunction solar cells. AIP Adv. 5, 077165 (2015)

54. Aspnes, D.E., Studna, A.: Dielectric functions and optical parameters of si, ge, gap, gaas, gasb, inp, inas, and insb from 1.5 to 6.0 ev. Phys. Rev. B. 27, 985 (1983)

55. Nikitin, A.Y., Guinea, F., García-Vidal, F., Martín-Moreno, L.: Edge and waveguide terahertz surface plasmon modes in graphene microribbons. Phys. Rev. B. 84, 161407 (2011)

56. Francescato, Y., Giannini, V., Maier, S.A.: Strongly confined gap plasmon modes in graphene sandwiches and graphene-on-silicon. New J. Phys. 15, $063020(2013)$

57. Yariv, A.: Introduction to Optical Electronics (1976)

58. Lasnier, F.: Photovoltaic Engineering Handbook. CRC Press (1990)

59. Liang, J., Bi, H., Wan, D., Huang, F.: Novel Cu nanowires/graphene as the back contact for CdTe solar cells. Adv. Funct. Mater. 22, 1267-1271 (2012)

60. Shi, Z., Jayatissa, A.H.: The impact of graphene on the fabrication of thin film solar cells: current status and future prospects. Materials. 11, 36 (2018)

61. Bi, H., Huang, F., Liang, J., Tang, Y., Lü, X., Xie, X., et al.: Large-scale preparation of highly conductive three dimensional graphene and its applications in CdTe solar cells. J. Mater. Chem. 21, 17366-17370 (2011)

\section{Publisher's Note}

Springer Nature remains neutral with regard to jurisdictional claims in published maps and institutional affiliations.

\section{Submit your manuscript to a SpringerOpen ${ }^{\circ}$ journal and benefit from:}

- Convenient online submission

- Rigorous peer review

- Open access: articles freely available online

- High visibility within the field

- Retaining the copyright to your article

Submit your next manuscript at $\boldsymbol{\nabla}$ springeropen.com 